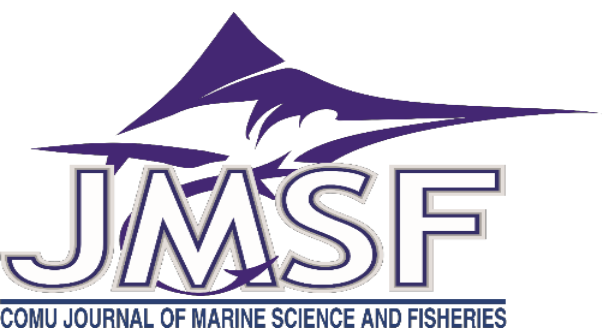

\title{
Visual Records of Lobotes surinamensis (Bloch, 1790) in the North-Eastern Mediterranean, Turkey
}

\author{
Deniz Ergüden $^{1 *}$, Deniz Ayas ${ }^{2}$, Sibel Alagöz Ergüden ${ }^{3}$ \\ ${ }^{1}$ Faculty of Marine Science and Technology, University of Iskenderun Technical, Iskenderun, Hatay, Turkey \\ ${ }^{2}$ Fisheries Faculty, Mersin University, Mersin, Turkey \\ ${ }^{3}$ Imamoglu Vocational School, Cukurova University, Adana, Turkey \\ Correspondent: deniz.erguden@iste.edu.tr; derguden@gmail.com \\ Received: 07.10.2020 Accepted: 26.11.2020 \\ Deniz Ergüden: Orcid 0000-0002-2597-2151 \\ Deniz Ayas: Orcid 0000-0001-6762-6284 \\ Sibel Alagöz Ergüden: Orcid 0000-0003-4363-433X
}

How to cite this article: Ergüden, D., Ayas, D. \& Alagöz Ergüden, S., (2020). Visual records of Lobotes surinamensis (Bloch, 1790) in the North-eastern Mediterranean, Turkey. COMU J. Mar. Sci. Fish, 3(2): 140-145. DOI: 10.46384/jmsf.807301

Abstract: In this study, five tripletails, Lobotes surinamensis, were reported for the first time in Mersin Bay (North-eastern Mediterranean coast of Turkey). Four juveniles were observed during diving expeditions in Yeşilovacık, Mersin Bay, on 04 November 2015 and 23 September 2016, while the fifth juvenile was recorded in Ayaş/Erdemli, Mersin Bay on 26 June 2018. This report is the first observation for this location and fills an essential gap in the species' range distribution. This study is also important as it is the first visual record of juveniles in this region. This finding will be helpful for both fisheries management and conservation efforts of this species.

Keywords: Lobotidae, Observation, Mersin Coast, Eastern Mediterranean, Turkey

\section{Kuzeydoğu Akdeniz, Türkiye'de Lobotes surinamensis'in (Bloch, 1790) Görsel Kayıtları}

Özet: $\mathrm{Bu}$ çalışmada, Mersin Körfezi'nde (Türkiye'nin Kuzeydoğu Akdeniz kıyısı) yüzeyde ve şamandıra çevresinde beş adet üç kuyruk, Lobotes surinamensis örneği rapor edilmiştir. 4 Kasım 2015 ve 23 Eylül 2016 tarihlerinde Mersin Körfezi Yeşilovacık'ta yapılan dalış sırasında L. surinamensis'in dört juvenil bireyi gözlendi ve L. surinamensis'in diğer yavru bireyi 26 Haziran 2018'de Mersin Körfezi Ayaş/Erdemli'de kaydedildi. Bu rapor, bu bölge için ilk gözlemdir ve türlerin yayılış alanı ve dağılımındaki önemli bir boşluğu doldurmaktadır. Bu çalışma, bu bölgedeki türlerin genç bireylerinin ilk görsel kayıtları nedeniyle de büyük önem taşımaktadır. Ayrıca, mevcut çalışma balıkçılık alanında faydalı olacak ve aynı zamanda bu türlerin hem balıkçılık yönetimine hem de korunmasına katkıda bulunacaktır.

Anahtar Kelimeler: Lobotidae, Gözlem, Mersin Sahili, Doğu Akdeniz, Türkiye

\section{Introduction}

The family Lobotidae is represented in the Mediterranean Sea by single genera as Lobotes. The tripletail L. surinamensis (Bloch, 1790) is a warm water marine fish species and usually solitary. It is found in tropical and subtropical waters (Carpenter, 2003). This species is distributed in the Western Atlantic: New England and Bermuda southward to Argentina and Falkland Islands, Eastern Atlantic: the Mediterranean Sea as well as from Madeira Island
(Portugal) to the Gulf of Guinea and Indo Pacific: Costa Rica to Peru, and the Western Pacific: Japan, Fiji, and Tuvalu as well as in the tropical and subtropical waters surrounding Australia (northern Australia to southern Queensland, New Guinea to New Britain and also reported as a rare presence from Ponape, Hawaii, and Tahiti (Froese \& Pauly, 2020). Deidun et al. (2010) stated that this species expanded from the Atlantic Ocean to the Mediterranean Sea via the Strait of Gibraltar. 
The first record of L. surinamensis species in the Mediterranean was in 1875 (Doderlein, 1875). Further reports of the occurrence of the species in the entire Mediterranean was made from Spain (Palom, 1991), Balearic islands (Riera, Grau, Grau, Pastor, Pou, \& Quetglas, 1999), Italian waters (Adriatic and central Mediterranean coast) (De Pirro, Tosi, \& Vanni, 1996; Zava, Gianguzza, \& Riggio, 2007; Bettoso, Comisso \& Kruzic, 2016; Tiralongo, 2016; Tiralongo, Coco, Lombardo \& Messina, 2018; Azurro et al., 2020), Crotian waters (Dulčić \& Dragičević, 2011; Dulčić, Dragičević, Lipej \& Štifanić, 2014), Maltese islands (Camilleri, Ragonese, Darmanin, \& Rosso, 2005; Deidun, Vella, Sciberras, \& Sammut, 2010), Ionian Sea (Licchelli \& Denitto, 2020), Aegean Sea (Bini, 1968; Economidis, 1973; Economidis \& Bauchot, 1976; Akyol \& Kara, 2012; Bilge, Filiz, \& Gülşahin, 2017), Turkish waters (Gücü \& Bingel, 1994, Başusta \& Erdem, 2000; Tuncer \& Önal, 2016; Ergüden, Ergüden, Bayhan, \& Altun, 2018), Cyprus coast (Kleitou \& Crocetta, 2016), Lebanon coast (Elbaraasi et al., 2019), the Greek Seas (Ondrias, 1971; Fischer, Bauchot, \& Schneider, 1987; Minos \& Economidis, 2007; Kavadas \& Bekas, 2014; Minasidis, Doumpas, Kleitou, Spryridopoulou, Papadamakis, \& Giovos, 2020), and Algerian coast (Hemida, Capape, Diatta, \& Golani, 2003), Tunisian waters (Qunifi-Ben Amor \& Ben Amor, 2016).
The tripletail L. surinamensis is a demersal and thermophilic species (Riede, 2004) that lives at depths from 0 to $70 \mathrm{~m}$ (Fricke, Kulbicki, \& Wantiez, 2011); it usually prefers brackish waters and shallow waters less than $10 \mathrm{~m}$ and (Myers, 1999; Kuiter \& Tonozuka, 2001). This species is abundant in the South and East Mediterranean (Akyol \& Kara, 2012; Bilge et al., 2016; Minasidis et al., 2020).

This study presents the first visual records of juvenile specimens of $L$. surinamensis in its natural habitat in Turkey's northeastern Mediterranean coast.

\section{Material and Methods}

Locations where L. surinamensis were observed are indicated in Figure 1. Four of the L. surinamensis specimens were observed on 2 different occasions, around a buoy near the surface during a diving expedition in Yeşilovacık (Mersin Bay) (Coordinate: $36^{\circ} 11^{\prime} 054^{\prime \prime} \mathrm{N}, 33^{\circ} 39^{\prime} 295^{\prime \prime E}$ ) on 04 November 2015 and 23 September 2016 (Figure 2). The other specimen of $L$. surinamensis was recorded in Ayaş/Erdemli (Coordinate: $36^{\circ} 29^{\prime} 076^{\prime}$ ' N, 34 $14^{\circ}$ $426^{\prime}$ 'E), Mersin Bay on 26 June 2018. This specimen was photographed during underwater diving at a depth of about $1 \mathrm{~m}$ by a digital underwater camera (Canon Powershot G12) (Figure 3). Species identification was carried out according to Heemstra (1986) and Tortonese (1990).

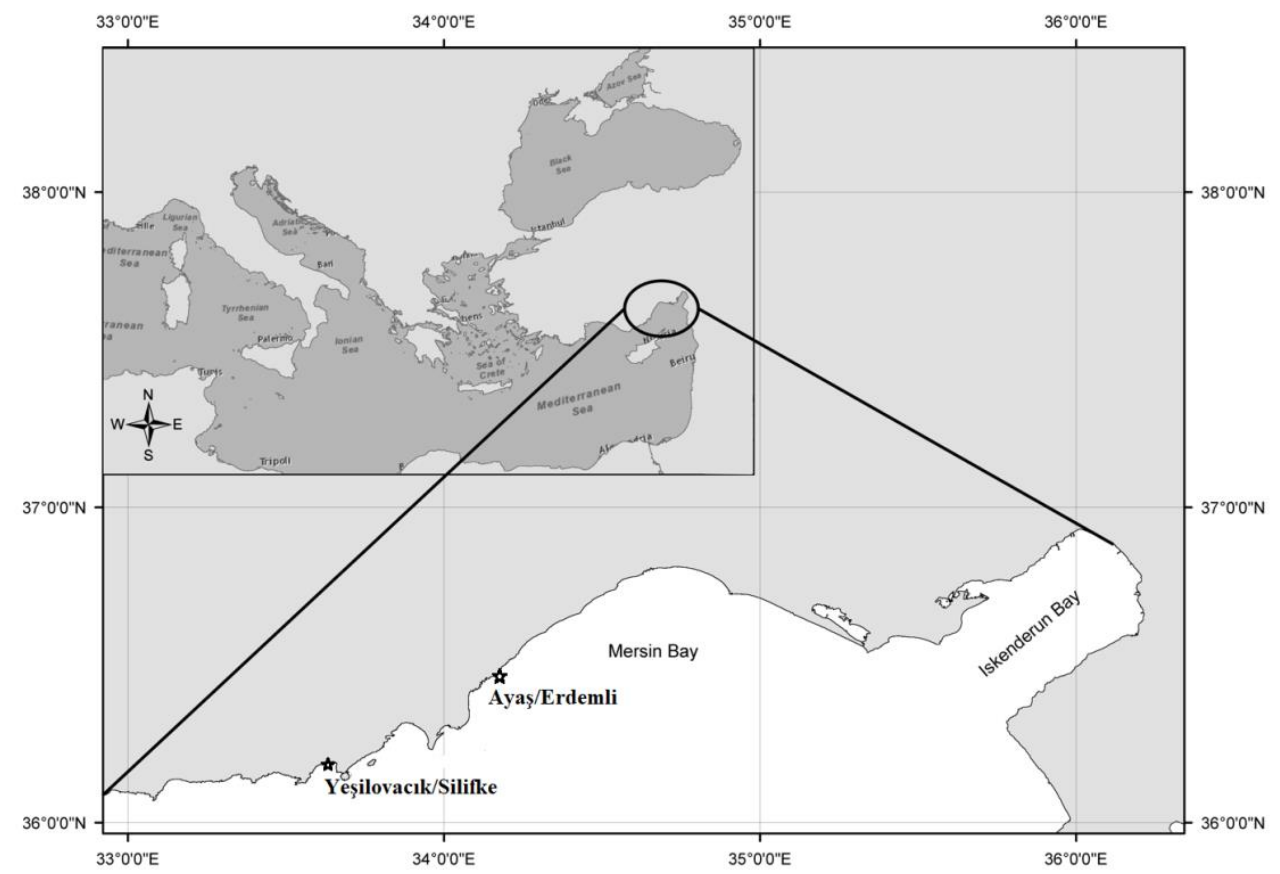

Figure 1. Locations of the occurrences of juvenile specimens of Lobotes surinamensis in Mersin Bay. Stars indicate locations. 


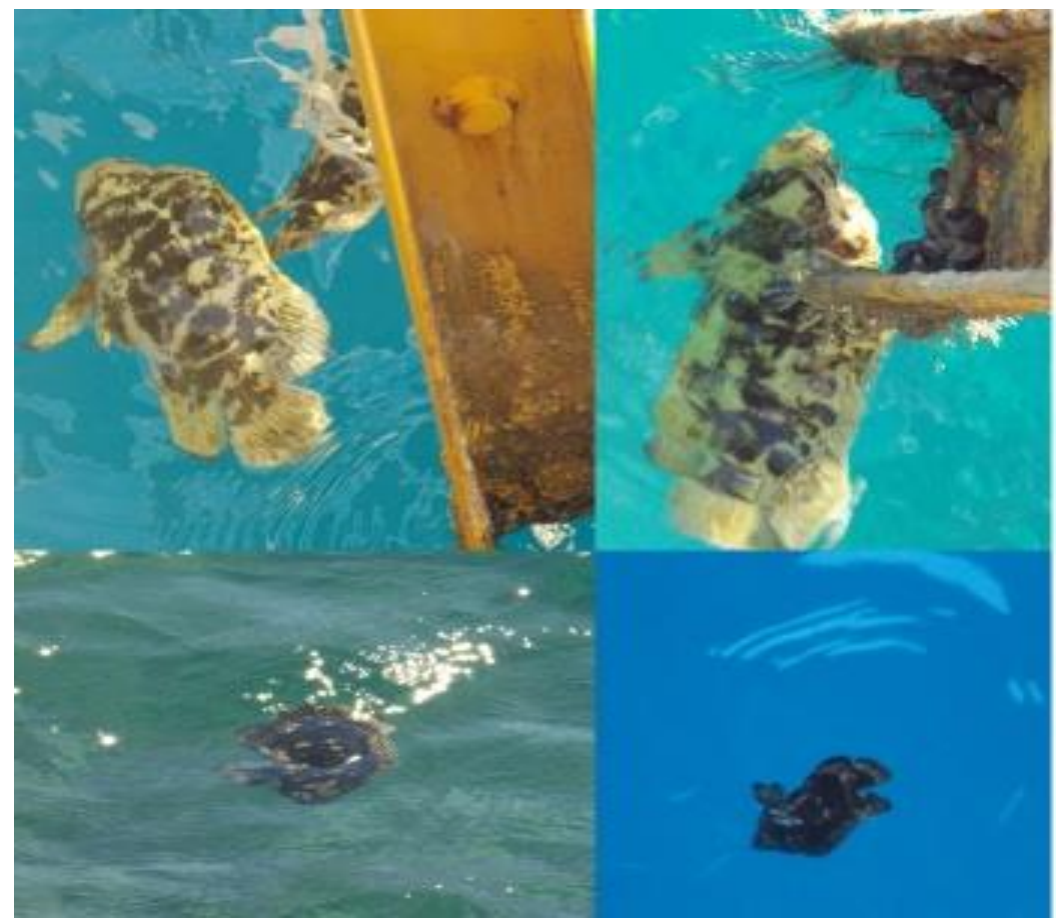

Figure 2. Four juvenile Lobotes surinamensis individuals visual recorded in the Yeşilovacık Bay, northeastern Mediterranean

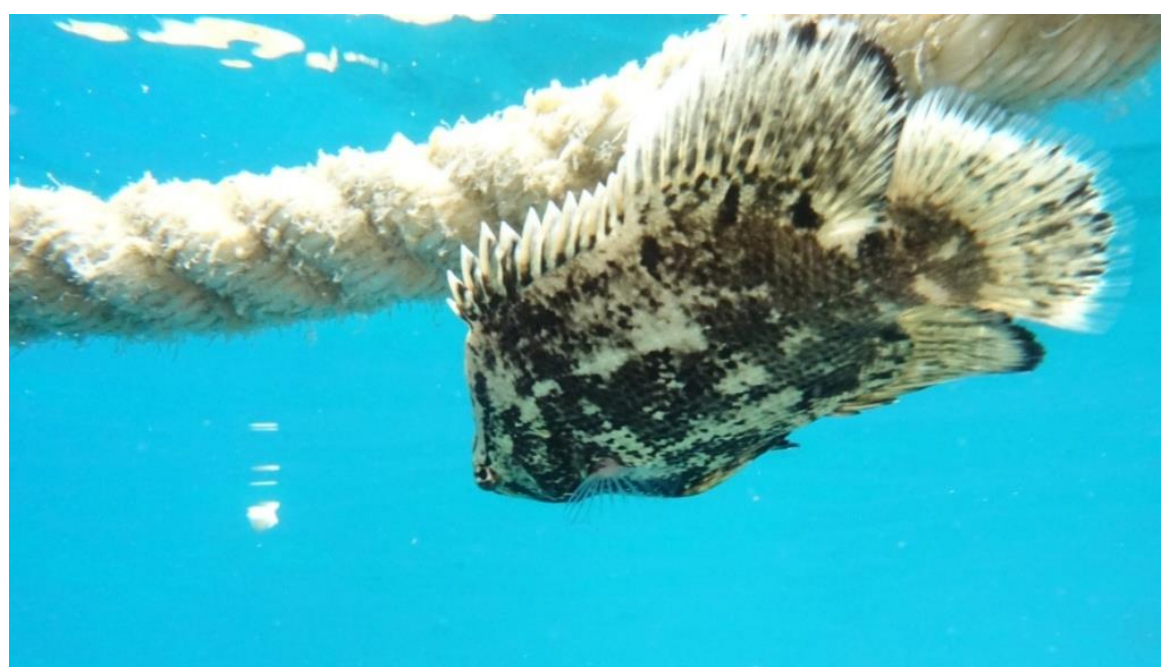

Figure 3. Juvenile Lobotes surinamensis underwater view recorded in the Erdemli coast, northeastern Mediterranean

\section{Results and Discussion}

The Atlantic tripletail is a very characteristic fish with a deep body and a triangle-shaped head. The eyes are small, but the mouth is large. The pectoral fins are shorter than the pelvic fins (Heemstra, 1986). Juvenile specimens are colored in a mottled yellow, brown, and black.

In this study, five individuals of $L$. surinamensis was observed and reported at 0-1 m depth in its natural habitat in Erdemli and Yeşilovacık coast (Mersin Bay). Specimens were observed around buoys on rocky and sandy bottoms, partially covered with barnacles and bivalves (Brachidontes pharaonis).

The maximum size of this species was reported as $110 \mathrm{~cm}$ in total length (TL) with typical TL of 80.0 cm by Robins \& Ray (1986), and Bouhlel (1988). In the present study, the size range of specimens approximately ranged between $25-30 \mathrm{~cm}$. It seems that this species recently established a population in the area of Yeşilovacık Bay, as indicated by the presence of a number of observed juveniles (Deniz Ayas, pers. comm.). 
Both juveniles and adults of tripletails are well known for their unusual behavior of floating just beneath the surface. (Menezes \& Figueiredo, 1980; Carvalho-Filho, 1999; Riera, Grau, Grau, Pastor, Pou, \& Quetglas) and occasionally drifts over reefs (Lieske \& Myers, 1994). Their presence near the surface may be related to feeding strategy. Prey items which tripletails feed on are probably also associated with the floating structures. However, L. surinamensis feed on a variety of foods, mostly small fish species and also benthic invertebrates.

Tripletail juveniles are usually found swimming on their side at the surface as single individuals or in very small groups consisting of two to four individuals (Breder Jr, 1949). Similarly, in this study, one single juvenile specimen was recorded from Erdemli coast close to the surface. The other 4 individuals were observed as a group on two different occasions in Yeşilovacık Bay. It is likely that this group of 4 juveniles observed in Yeşilovacık Bay on November $4^{\text {th }} 2015$, were the same group consisting 4 juveniles observed 11 months later, on September $23^{\text {rd }}, 2016$, in the same location.

Although the tripletail has been reported from the Mediterranean Sea and the Aegean Sea previously, we report the presence of $L$. surinamensis individuals for the first time from Mersin coasts in the northeastern Mediterranean, Turkey, based on underwater sightings and surface photographs in their natural habitat.. Our findings are the first visual records of juvenile specimens of this species in the northeastern Mediterranean coast of Turkey.

The tripletail is mainly caught using haul seines, gill nets, and line gear but they are also infrequently targeted by recreational fishers. To date, there is no significant unknown threat to the Mediterranean population. In Turkey there no data on commercial fisheries of this species as it is still rare to be considered as an economical species. However, monitoring studies are needed to obtain data on the Mediterranean population of this species in Turkey. This study will be useful for studying the natural habitats of juvenile tripletails and will also contribute to sustainability and conservation of this species in the future.

\section{References}

Akşıray, (1987). Türkiye Deniz Balıkları ve Tayin Anahtarl. (II. Baskl), (811 p.). İstanbul: İstanbul Üniversitesi Rektörlüğü Yayınları.

Akyol, O., \& Kara, A. (2012). Record of the Atlantic tripletail, Lobotes surinamensis (Bloch, 1790) in the Bay of Izmir, northern Aegean Sea. Journal of Applied Ichthyology, 28, 645-646. doi: 10.1111/j.1439-0426.2012.01939.x.
Azzurro, E., Bariche, M., Bolognini, L., Cerri, J., Gianni, F., Sbragaglia, V., \& Souissi, J. B. (2019). Climate change, biological invasions, and the shifting distribution of Mediterranean fishes: a large-scale survey based on local ecological knowledge. Global Change Biology, 25(8), 2279-2792. doi: 10.31230/osf.io/zgupd.

Başusta, N., \& Erdem, Ü. (2000). İskenderun Körfezi balıkları üzerine bir araştırma. Turkish Journal of Zoology, 24, 1-19.

Bettoso, N., Comisso, G., \& Kruzic, P. (2016). First record of the tripletail Lobotes surinamensis (Pisces: Lobotidae) in the lagoon of Marano and Grado (Gulf of Trieste, northern Adriatic Sea). Annales Series Historia Naturalis, 26(2), 209-212.

Bilge, G., Filiz, H., \& Gülşahin, A. (2017). Occurrence of Lobotes surinamensis (Osteichthyes: Lobotidae) in the Mediterranean: historical and recent data. Zoology in the Middle East, 63, 43-47. doi: 10.1080/09397140.2017.1269392.

Bini, G. (1968). Un pesce perciformera roper i mar iItaliani "Lobotes surinamensis, (Bloch 1790)". Atti della Accademia Peloritana dei Pericolanti Classedi Scienze Fisiche Matematiche e Naturali, 14(1/2), 3-7.

Bouhlel, M. (1988). Poissons de Djibouti. (416 p.). RDA Placerville, California, USA: International, Inc.

Breder, Jr C. M. (1949). On the behavior of young Lobotes surinamensis. Copeia, 4, 237-242. doi: $10.2307 / 1438372$.

Camilleri, M., Ragonese, S., Darmanin, M., \& Rosso, B. (2005). The discovery of a specimen of Lobotes surinamensis off the Maltese islands (Central Mediterranean Sea). Biologia Marina Mediterranea, 12, 480-483.

Carpenter, K. E. (2003). Lobotidae. Tripletails. In K.E. Carpenter (Ed.), FAO species identification guide for fishery purposes. The living marine resources of the Western Central Atlantic. Bony fishes Part 2 (Opistognathidae to Molidae), sea turtles and marine mammals. Vol. 3, (pp. 1505): FAO, Rome.

Carvalho-Filho, A. (1999). Peixes: costabrasileira (3rd ed). São Paulo: Melro Editora.

De Pirro, M., Tosi, G., \& Vanni, S. (1996). Terza cattura nei mari Italiani di Lobotes surinamensis (Bloch, 1790) (Actinopterygii, Perciformes, Lobotidae). Atti della Societa Toscana de Scienze Naturali di Pisa, Serie B 103, 113-114.

Deidun, A., Vella, P., Sciberras, A., \& Sammut, R. (2010). On the increasing occurrence of Lobotes

surinamensis in Maltese coastal waters. Aquatic 
Invasions, 5(Supp 1), 113-116. doi: 10.3391/ai.2010.5.S1.023.

Doderlein, P. (1875). Descrizioned i una specie di pesce del genere esotico Lobotes, presonelle acque dei contornidi Palermo. Atti della Accademia di Scienze Lettere e Artidi Palermo, 5(3), 1-12.

Dulčić, J., \& Dragičević, B. (2011). First record of the Atlantic tripletail, Lobotes surinamensis (Bloch, 1790), in the Adriatic Sea. Journal of Applied Ichthyology, 27, 1385-1386. doi:10.1111/j.14390426.2011.01808.x.

Dulčić, J., Dragičević, B., Lipej, L., \& Štifanić, M. (2014). Range extension of tripletail Lobotes surinamensis (Lobotidae) in the Adriatic Sea. A northernmost record in the Mediterranean. Cybium, 38, 153-154. doi: 10.26028/cybium/2014382-007.

Economidis, P. S. (1973). Cataloque de Poisons de la Grèce. Hellenic Oceanology and Limnology, 11, 421-598.

Economidis, P. S., \& Bauchot, M. L. (1976). Sur une collection de poissons des mershélleniques (mers Égée et Ionienne) déposéeau Muséum national d' histoire naturelle. Bulletin du Museum National d'Histoire Naturelle. Zoologie, Paris, 3e Serie, No 392, Zoology, 274, 871-903.

Elbaraasi, H., Azzurro, E., Bashir, A., Elaabidi, S., Elabar, B., Elsilini, O., \& Shakman, E, (2019). Updated checklist of bony fishes along the Libyan coasts (southern Mediterranean Sea). Mediterranean Marine Science, 20(1), 90-105. doi: 10.12681/mms. 15570 .

Ergüden, D., Çekiç, M., Ergüden, S. A., Bayhan, Y. K., \& Altun, A. (2018). Juvenile records on the tripletail, Lobotes surinamensis (Bloch, 1790) from Iskenderun Bay (Northeastern Mediterranean Sea, Turkey). Acta Biologica Turcica, 31(2), 4245.

Fischer, W., Bauchot, M. L., \& Schneider, M. S. (1987). Fishes FAO d' identification de sespèces pour les besoins de la Pêche (Revision 1). Zone de pêche 37. Vol 2, (pp. 761-1530): Vertébrés. FAO et CEE Publishers, Rome.

Fricke, R., Kulbicki, M., \& Wantiez, L. (2011). Checklist of the fishes of New Caledonia, and their distribution in the Southwest Pacific Ocean (Pisces). Stuttgarter Beiträgezur Naturkunde A, Neue Serie, 4, 341-463.

Froese, R., \& Pauly, D. (2020). Fishbase. World Wide Web Electronic Publication. [version 12/2019] http://www.fishbase.org/Accessed 05 October 2020.

Gücü, A. C., \& Bingel, F. (1994). Trawlable species assemblages on the continental shelf of the northeastern Levant Sea (Mediterranean) with an emphasis on Lessepsian migration. Acta Adriatica, $35,83-100$

Heemstra, P. C. (1986). Lobotidae. In M.M. Smith, \& P.C. Heemstra (Eds.), Smiths' Sea Fishes (pp. 621622): Springer-Verlag, Berlin.

Hemida, F., Capape, C., Diatta, Y., \& Golani, D. (2003). On the occurrence of tripletail, Lobotes surinamensis (Bloch, 1790) (Osteichthyes: Lobotidae) off the coast of Algeria (southern Mediterranean). Annales Series Historia Naturalis, 13, 145-148.

Kavadas. S., \& Bekas, P. (2014). New record of Lobotes surinamensis (Bloch, 1790) from Maliakos Gulf (Central Aegean Sea, Greece). New Mediterranean Biodiversity Records (October, 2014), Mediterranean Marine Science, 15(3), 691. doi: $10.12681 / \mathrm{mms} .1123$.

Kleitou, P., \& Crocetta, F. (2016). First record of the rare native fish Lobotes surinamensis (Bloch, 1790) in Cyprus. New Mediterranean Biodiversity Records (November, 2016), Mediterranean Marine Science, 17(3), 813. doi: 10.12681/mms.1976.

Kuiter, R. H., \& Tonozuka, T. (2001). Pictorial guide to Indonesian reef fishes. Part 2. (304-622 p.). Australia: Fusiliers - Dragonets, Caesionidae Callionymidae. Zoonetics.

Licchelli, C., \& Denitto, F. (2020). First record of Lobotes surinamensis (Bloch, 1790) in the north Ionian Sea. New records of rare species in the Mediterranean Sea, Mediterranean Marine Science, 21(2), 348. doi: 10.12681/mms.22148.

Lieske, E., \& Myers, R. (1994). Collins Pocket Guide. Coral reef fishes. (400 p.). Indo-Pacific and Caribbean including the Red Sea. Harper Collins Publishers.

Menezes, N. A., \& Figueiredo, J. L. (1980). Manual de peixes marinhos do sudeste do Brasil. IV. Teleostei (3). São Paulo: Museu de Zoologia da Universidade de São Paulo.

Minos, G., \& Economidis, P. S. (2007). On the occurrence of tripletail, Lobotes surinamensis(Bloch, 1790) (Pisces: Lobotidae), in North AegeanSea (Greece). (242 p.). 12th European Congress of Ichthyologists. 9-13 September 2007, Cavat (Dubrovnik), Croatia.

Myers, R. F. (1999). Micronesian reef fishes: a comprehensive guide to the coral reef fishes of Micronesia. (3rd revised and, expanded edition), (330 p.). Barrigada, Guam: Coral Graphics.

Minasidis, V., Doumpas, N., Kleitou, P., Spryridopoulou, R. N. A., Papadamakis, P., \& Giovos, I. (2020). Additional records of tripletail Lobotes surinamensis (Bloch, 1790), from the 
Eastern Mediterranean. Thalassas: An International Journal of Marine Sciences, 36, 557 563. doi: 10.1007/s41208-020-00244-6.

Ondrias, J. C. (1971). A list of the fresh and sea water fishes of Greece. Hellenic Oceanology and Limnology, 10, 23-96.

Palom, O. (1991). Primeracita de Lobotes surinamensis (Bloch, 1790) (Pisces, Lobotidae) para la ictiofauna Iberica. Miscellania Zoologica, $15,240-242$.

Qunifi-Ben Amor, K., \& Ben Amor, M. M. (2016). Unusual records of tripletail Lobotes surinamensis (Osteichthyes: Lobotidae) from the Tunis Southern Lagoon (North-EasternTunisia, Central Mediterranean Sea). Annales Series Historia Naturalis, 26, 13-18.

Riera, F, Grau, A., Grau, A. M., Pastor, E., Pou, S., \& Quetglas, A. (1999). Ichthyofauna associated with drifting floating objects in the Balearic Islands (western Mediterranean). Scienta Marina, 63, 229235.

Riede, K. (2004). Global register of migratory species from global to regional scales. Final Report of the R\&D-Projekt 80805 081. (329 p.). Federal Agency for Nature Conservation, Bonn, Germany.

Robins, C. R., \& Ray, G. C. (1986). A field guide to Atlantic coast fishes of North America. (354 p.). Boston, U.S.A: Houghton Mifflin Company.
Tortonese, E. (1990). Lobotidae. In J. C. Quero, J. C. Hureau, C. Karrer, A. Post \& L. Saldanha (Eds.), Check-list of the fishes of the eastern tropical Atlantic (CLOFETA). Vol. 2, (p. 780). JNICT, Lisbon; SEI, Paris; and UNESCO, Paris.

Tiralongo, F. (2016). New record of Lobotes surinamensis (Bloch, 1790) from Italian waters (Adriatic Sea). In Dailianis et al. (Eds.), New Mediterranean Marine Biodiversity Records (July, 2016), Mediterranean Marine Science, 17(2), 608626. doi: 10.12681/mms.1734.

Tiralongo, F., Coco, S., Lombardo B. M., \& Messina, G. (2018). On the presence of a well-established population of Lobotes surinamensis (Bloch, 1790) in the Central Mediterranean Sea. Annales Series Historia Naturalis, 28(1), 31-36.

Tuncer, S., \& Önal, U. (2016). The occurrence of the Atlantic tripletail, Lobotes surinamensis (Bloch, 1790), in the Çanakkale Strait. New Mediterranean Biodiversity Records (March 2016), Mediterranean Marine Science, 17(1), 247-248. doi: $10.12681 / \mathrm{mms} .1684$.

Zava, B., Gianguzza, P., \& Riggio, S. (2007). New capture of the tripletail Lobotes surinamensis (Bloch, 1790) in the southern Tyrrhenian Sea (Osteichthyes: Lobotidae). Biologia Marina Mediterrenae, 14, 370. 